\title{
Hiring \& Managing A Millennial Workforce
}

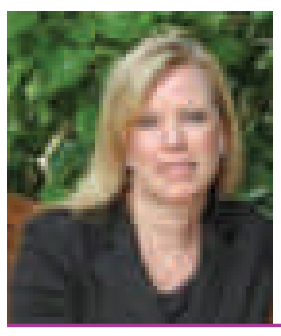

Trudi Charest, RO

Trudi Charest is the Co-Founder of 4ECPs, a business resource company for eyecare

professionals. 4ECPs has six divisions, marketing, training, social media, jobsite, payments Et events. Trudi can be reached at www.4ecps.com or trudi@4ecps.com.

he average Canadian Optometry practice is shifting. Millennial employees are quickly becoming the majority of staff in an Optometry practice. Millennials change careers more than any other previous generation so becoming a better recruiter will be a crucial business skill as you will be hiring more frequently than before.

Millennials were born between 1981 - 1997, and represent the largest generation in Canada. This generation grew up with technology at their fingertips and social media is a way of life. They are highly educated and culturally diverse. They have high expectations, lower loyalty standards and are fiercely independent. Since they are the workforce of the future it is important to know how to attract and retain the millennial worker.

ATTRACTING MILLENNIALS:

1. Money...is important. This generation will move for even a small raise so make sure your pay is competitive in the industry or slightly higher if you can afford it.

2. Work-life balance is critical. These employees are all about life...they work to live. Don't expect them to work overtime or weekends without some serious compensation.

3. Write a compelling ad. Don't under estimate the fact this generation is tech savvy, so they will be able to search all open job positions quickly and they are looking to be inspired. Make them want to work for you.

4. Make it easy to apply. Don't tell them to "drop" off a resume at the practice. These guys are all about the internet so the easier you can make it to send you a resume the more resumes you will get.

5. Your online presence precedes you. They are checking you out right now before they send a resume....does your online presence look modern and updated? That's important to Millennials...they don't want to work for someone "behind the times".

RETAINING MILLENNIALS:

1. Money....yep, here it is again! Pay increases and bonuses are important. It might be time to rethink your raise strategy. Smaller, more frequent raises will work better than annual raises.

2. Career path. Find ways to create career paths for all your employees. It could be as simple as a Junior Optician to a Senior Optician where they earn a new title \& responsibility as well as a small increase.

3. Growth. They want to continue to learn and grow and feel like they are moving forward in their careers. They have had more school than any other generation and like the access to continued learning.

4. Recognition. Millennials are no different in this respect than any other generation...we all like to hear good things about our work and efforts. Take the time to recognize individuals every opportunity. 
5. Work-life balance and flexibility. It's hard in our set practice hours to provide flexibility but it continues to be one of the most favored concessions for employees. Other concessions include extra holidays, working from home and setting own hours. How can you be flexible?

\section{WHAT MILLENNIALS WANT FROM THEIR COMPANY!}

- Develop my skills for the future

- Have strong company values

- Offer customized options in my benefit package

- Allow me to blend work with the rest of my life

- Clear career path

*Harvard Business Review

Last note: The No. 1 reason Millennials leave companies is that they don't feel valued or respected. This generation has had a bad rap about being less motivated and more entitled. I have 27 Millennial workers in my company and I find they work hard, go the extra mile and show great initiative when valued and treated well.

Sources:

Extreme.tech/2017/01/20/millennials-canadian-workforce

Harvard Business Review

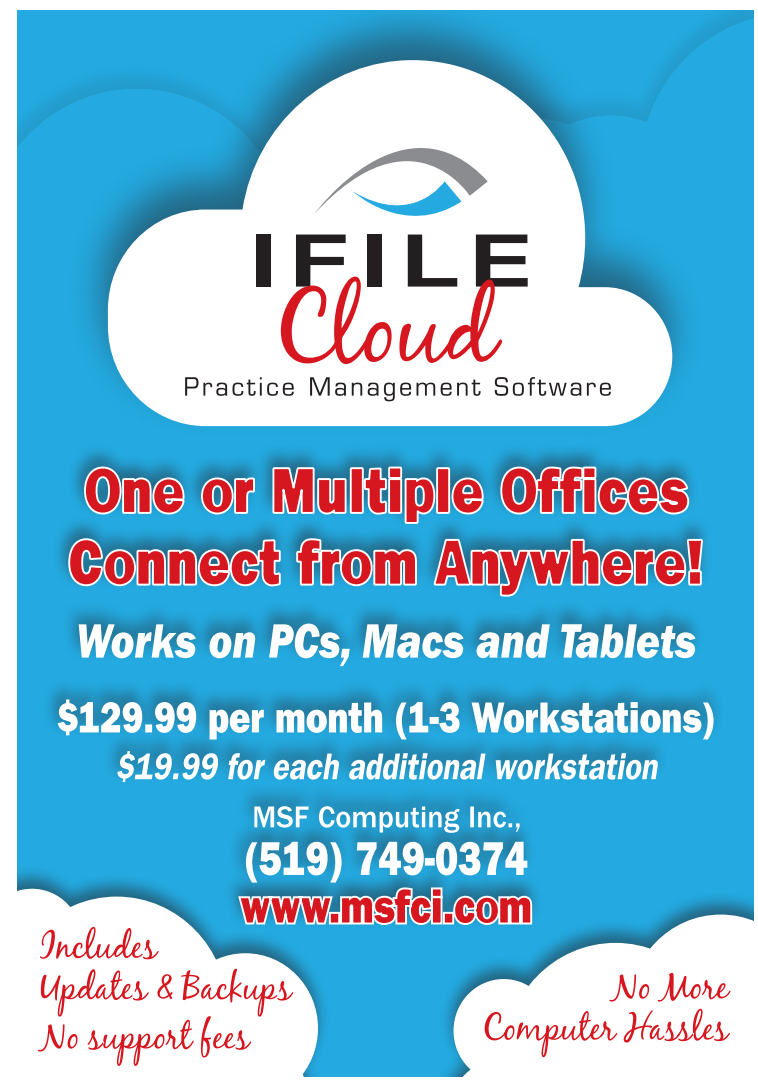

